\begin{tabular}{|c|c|c|c|}
\hline & $\begin{array}{l}\text { FATIH } \\
\text { SULTAN } \\
\text { MEHMET } \\
\text { VAKIF ÜNivERSiTESi }\end{array}$ & $\begin{array}{l}\text { FSM IImî Araştırmalar Insan ve Toplum Bilimleri Dergisi } \\
\text { FSM Scholarly Studies Journal of Humanities and Social Sciences } \\
\text { Sayı/Number } 17 \text { Yıl/Year } 2021 \text { Bahar/Spring } \\
\text { (c)2021 Fatih Sultan Mehmet Vakıf Üniversitesi }\end{array}$ & 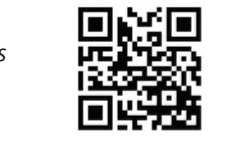 \\
\hline DOI: & & http://dergipark.org.tr/fsmia & http://dergi.fsm.edu.tr \\
\hline Araştır & alesi / Research Article & Geliş Tarihi / Received: 01.05.2021 Kabul Tarihi / Accepted: 17.05.2021 & FSMIAD, 2021; (17): 437-454 \\
\hline
\end{tabular}

\title{
Bilgi ve Belge Yönetimi Öğreniminde Meslekî Aidiyet ve Stajlar Mehlika Karagözoğlu Aslıyüksek*
}

\section{Öz}

Bir çalışanın mesleğine kişisel ve psikolojik olarak bağlılığını ifade eden meslekî aidiyet kavramı, bütün disiplinler gibi Bilgi ve Belge Yönetimi alanı için de önem arz etmektedir. Bilgi merkezlerinin en iyi performansla çalışmasını sağlayacak olan meslekî aidiyetin kazanılması üniversite öğrenimi ve stajlar sırasında başlamaktadır. Bu araştırmada, Marmara Üniversitesi Bilgi ve Belge Yönetimi Bölümü öğrencilerinin meslekî aidiyet düzeyleri çeşitli değişkenlere göre incelenmiştir. Çalışmada, Rıdvan Keskin ve M. Nur Pakdemirli tarafından hazırlanan Meslekî Aidiyet Ölçeği'nin ikinci faktörü kullanılmıştır. Veriler SPSS 22.0 programı kullanılarak analiz edilmiştir. Verilerin değerlendirilmesinde sayı, yüzde, ortalama, standart sapma, t-testi ve Tek Yönlü Anova Testi kullanılmıştır. Anova testi sonrasında farklılıkları belirlemek üzere tamamlayıcı post-hoc analizi olarak Scheffe testi kullanılmıştır. Araştırma sonunda öğrencilerin öğrenim gördükleri alana dair meslekî aidiyet düzeylerinin yüksek olduğu görülmüştür. Bununla birlikte araştırma kitlesinde staj yapma durumu ile meslekî aidiyet arasında ters bir orantı olduğu saptanmıştır.

Anahtar Kelimeler: Meslekî aidiyet, Bilgi ve Belge Yönetimi, staj.

* Dr. Öğr. Üyesi, Marmara Üniversitesi Bilgi ve Belge Yönetimi Bölümü, İstanbul/Türkiye, mehlikakaragozoglu@marmara.edu.tr, orcid.org/0000-0003-1198-5872 


\title{
Professional Commitment and Internships in Information and Records Management Studies
}

\begin{abstract}
Professional commitment, which expresses the personal and psychological commitment of an employee to his profession, is also important for the field of Information and Records Management like all disciplines. Acquisition of professional commitment, that will enable information centers to work with the best performance, starts during university studies and internships. In this study, the professional commitment levels of Marmara University Information and Records Management Department students, has been examined according to various variables. In the study, the second factor of the Professional Commitment Scale which prepared by Ridvan Keskin and M. Nur Pakdemirli, is used. The data were analyzed using the SPSS 22.0 program. Number, percentage, mean, standard deviation, t-test and One-Way Anova Test were used to evaluate the data. After the Anova test, the Scheffe test was used as a complementary post-hoc analysis to determine the differences. At the end of the research, it was observed that the students' level of professional commitment was high. However, it was found that there is an inverse proportion between the internship and professional commitment, among the research population.
\end{abstract}

Keywords: Professional commitment, Information and Records Management, internship. 


\section{Giriş}

Meslekî aidiyet kavramı bir çalışanın mesleğine kişisel ve psikolojik olarak bağlılığını ifade eder. Çalışanın psikolojik anlamda taşıdığı aidiyet duygusu, kurumuna karşı hissettiği sorumluluğun bir göstergesidir ve verdiği hizmetin niteliğine etki eder. Aidiyet duygusunun oranı, kişinin çalışma alanındaki üretimini ve performansını belirleyecek güce sahiptir. Lee, Carswell ve Allen'ın bulgularına göre meslekî aidiyet, iş performansını doğrudan etkilemektedir. ${ }^{1}$

İlk kez 1971 yılında Greenhaus (1971) tarafindan tanımlanan meslekî aidiyet kavram1, uluslararas1 literatürde "professional commitment", "occupational commitment", "career commitment", "work commitment" ve "job commitment" gibi kavramlarla; ulusal literatürde ise "meslekî bağll lık", "mesleğe bağlllık", "meslekle özdeşleşme”, "meslekî değerlerle özdeşleşme”, "meslekî adanmışlık", "kariyer bağglllı̆gl" ve "işe bağll lık" gibi kavramlarla ifade edilmektedir.

Son yıllarda yapılan aidiyet ile ilgili çalışmalar, disiplinlerin meslekî aidiyet konusunda bilinçlenmelerini sağlarken, kurum ve işletmelerin de çalışanlarının aidiyet düzeylerini yükseltmek üzere çalışmalar yapmasını sağlamıştır. Artık insan kaynakları birimleri, kişilerin kurumlarına bağlılıklarını ve dolayısıyla verimliliklerini arttırmayı amaçlamaktadır.

Kütüphaneler, arşivler ve bilgi merkezleri, sosyal kâr amacı güden işletmeler olarak iyi performanslar sergilemek için hevesle çalışan, meslekî aidiyeti yüksek personele ihtiyaç duymaktadır. Kütüphaneci, arşivci ya da bilgi yöneticisi, meslekî aidiyet bilincini meslekle tanıştığ 1 ve staj yaparak ilk meslekî tecrübelerini edindiği üniversite öğrenciliği sırasında kazanmaya başlamaktadır. Bununla birlikte, öğrencilerin meslekî aidiyet düzeyleri sınıflarına ve staj yapıp yapmama durumlarına göre değişiklik göstermektedir. Bu çalışmada, gelecekte bilgi ve belge merkezlerinde çalışacağı öngörülen Bilgi ve Belge Yönetimi (BBY) Bölümü öğrencilerinin meslekî aidiyet düzeyleri incelenmektedir.

\section{Araştırmanın Amacı Kapsamı ve Yöntemi}

Marmara Üniversitesi Bilgi ve Belge Yönetimi Bölümü, Fen-Edebiyat Fakültesi içinde dört yıllık bir lisans programıdır. Öğrenciler ikinci sınıfı ve üçüncü

1 K. Lee - J. J. Carswell - N. J. Allen, “A meta-analytic review of occupational commitment: Relations with person- and work-related variables", Journal of Applied Psychology, 85(5), 2000, p. 808.

2 S. Kardeş Selimoğlu - G. Yeşilçelebii, "Meslekî aidiyetin bağımsız denetim kalitesi üzerine etkisi: Bağımsız denetçiler üzerine bir araştırma", Muhasebe ve Finansman Dergisi, (64), 2014, s. 28. 
sınıfı tamamladıkları yaz tatillerinde kütüphaneler, arşivler, müzeler veya çeşitli bilgi merkezlerinde yirmişer günlük iki zorunlu staj yapmaktadır. Staj uygulamasının amacı, öğrencilerin bölümde teorik ve yarı uygulamalı olarak aldıkları Bilgi ve Belge Yönetimi (BBY) öğrenimini, uygulamalı olarak desteklemek, ileride çalışabilecekleri iş ortamlarını tanıyıp kavramalarını sağlamak ve elbette bir meslekî aidiyet oluşturmaktır.

BBY bölümü öğrencilerinin öğrenim gördükleri alana dair meslekî aidiyet düzeylerini incelemeyi ve bunu Marmara Üniversitesi (MÜ) örneğinde ortaya koymaya amaçlayan bu araştırmada aşağıdaki sorulara cevap aranmıştır:

1. Marmara Üniversitesi Bilgi ve Belge Yönetimi Bölümü (MÜBBY) öğrencilerinin öğrenim gördükleri alana dair meslekî aidiyet düzeyleri nedir?

2. Cinsiyet, yaş, sınıf, staj yapıp yapmama durumu, staj yeri ve staj sayısı değişkenlerinin öğrencilerin meslekî aidiyet düzeylerine etkisi var mıdır?

Araştırmanın evreni 2018 Öğretim Yılı Bahar yarıyılında MÜBBY bölümüne kayıtlı lisans öğrencilerinden oluşmaktadır. Çalışmada toplam 246 form doldurtulmuş, bunların 20 tanesi eksik ya da hatalı işaretleme sebebiyle araştırma kapsamı dışında bırakılmıştır. Sonuç olarak 226 geçerli form kullanılarak gerçekleştirilen araştırmada elde edilen veriler SPSS (Statistical Package for Social Sciences) for Windows 22.0 programı kullanılarak analiz edilmiştir. Verilerin değerlendirilmesinde tanımlayıcı istatistiksel yöntemlerden sayı, yüzde, ortalama, standart sapma kullanılmıştır. İki bağımsız grup arasında niceliksel sürekli verilerin karşılaştırılmasında t-testi, ikiden fazla bağımsız grup arasında niceliksel sürekli verilerin karşılaştırılmasında Tek Yönlü Anova Testi (One way Anova Test) kullanılmıştır. Anova testi sonrasında farklılıkları belirlemek üzere tamamlayıcı post-hoc analizi olarak Scheffe testi kullanılmıştır.

Çalışmada, Rıdvan Keskin ve M. Nur Pakdemirli (2016) tarafından hazırlanan Meslekî Aidiyet Ölçeği'nin ${ }^{3} 16$ maddelik Meslekî Örgüt Aidiyeti adlı ikinci faktörü kullanılmıştır. Keskin ve Pakdemirli’nin ölçeğindeki 20 ve 21 . maddeler (bu çalışmanın formunda 15 ve 16. maddeler) üzerinde uyarlama yapılmış; 2.,12.,13. ve 14. maddelere ise yalnızca kip değişikliğini gösteren birer kelime eklenmiş, bu kelime parantez içinde verilmiştir. 14. maddede bir sözcüğe parantez içinde çokluk eki eklenmiştir. Yapılan tüm uyarlamalar Tablo 1 'de gösterilmektedir.

3 R. Keskin - M.N. Pakdemirli, "Meslekî aidiyet ölçeği: Bir ölçek geliştirme, geçerlilik ve güvenirlik çalışması", Journal of International Social Research, 9, 2016, s. 2580-2580. 
Tablo 1. Uyarlanan ölçek maddeleri

\begin{tabular}{ll}
\hline Orijinal ölçek & Kullanılan uyarlama ölçek \\
\hline $\begin{array}{l}\text { 20.Bu kurumda görev yapmaktan } \\
\text { memnunum. }\end{array}$ & $\begin{array}{l}\text { 15. Bu bölümde eğitim almaktan } \\
\text { memnunum. }\end{array}$ \\
$\begin{array}{l}\text { 21. Emekli olduğumda bile kurumuma } \\
\text { aidiyetimi sürdüreceğime inanıyorum. }\end{array}$ & $\begin{array}{l}\text { 16. Mezun olduğumda bile bölümüme } \\
\text { aidiyetimi sürdüreceğime inanıyorum. }\end{array}$ \\
$\begin{array}{l}\text { 2. Mesleğimde başarılı olduğumu } \\
\text { düşünüyorum. }\end{array}$ & $\begin{array}{l}\text { 2. Mesleğimde başarılı olduğumu / } \\
\text { olacağımı düşünüyorum. }\end{array}$ \\
$\begin{array}{l}\text { 12. Görev yaptığım kurumların toplumda } \\
\text { olumlu bir imajı vardır. }\end{array}$ & $\begin{array}{l}\text { 12. Görev yaptığım/yapacağım } \\
\text { kurumların toplumda olumlu bir imajı }\end{array}$ \\
$\begin{array}{l}\text { vardır. } \\
\text { imajı̈na önem verir, iyi temsil etmeye } \\
\text { çalışırım. }\end{array}$ & $\begin{array}{l}\text { 13. Görev yaptığım/ yapacağım kurumun } \\
\text { toplumsal imajına önem verir, iyi temsil } \\
\text { etmeye çalışırım. }\end{array}$ \\
$\begin{array}{l}\text { 14. Bu kurumda görev yapmanın } \\
\text { meslekî gelişimime katkı sağladığını }\end{array}$ & $\begin{array}{l}\text { 14. Bu kurum(lar)da görev yapmanın } \\
\text { düşünüyorum. }\end{array}$ \\
\hline
\end{tabular}

$\mathrm{Bu}$ araştırmada Meslekî Örgüt Aidiyeti faktörünün güvenirliği Cronbach’s Alpha $=0,928$ olarak yüksek bulunmuştur.

\section{Bulgular}

Araştırmanın bulguları, demografik verilere ilişkin bulgular, meslekî aidiyete ilişkin bulgular ve ölçek maddelerine göre meslekî aidiyet bulguları olarak başlıklandırılmıştır.

\section{Demografik verilere ilişskin bulgular}

Araştırmaya katılan öğrencilerin 153〉ü $(\% 68,0)$ kadın, 72〉si $(\% 32,0)$ erkek olarak dağılmaktadır. Öğrencilerin 10>u $(\% 4,4)$ sınıfını belirtmeyenlerden, 44>ü $(\% 19,6)$ birinci sinıflardan, 48>i $(\% 21,3)$ ikinci sinıflardan, 53>ü $(\% 23,6)$ üçüncü sınıflardan, 70>i (\%31,1) dördüncü sınıflardan oluşmaktadır. Öğrencilerin 122>si $(\% 54,2)$ daha önce staj yapmış, 103)ü $(\% 45,8)$ henüz hiç staj yapmamıştır. Staj yapan öğrencilerin 58>i $(\% 47,5)$ bir staj yapmışken; 64'ü $(\% 52,5)$ iki staj yapmıştır. Öğrencilerin 46's1 $(\% 37,7)$ kütüphanede, 20'si $(\% 16,4)$ arşivde, 11'i $(\% 9,0)$ büroda, 45 'i $(\% 36,9)$ ise hem kütüphanede hem de arşiv veya büroda staj yapmıştır. (Tablo 2) 
Tablo 2. Öğrencilerin demografik özellikleri

\begin{tabular}{llll}
\hline Tablolar & Gruplar & Frekans(n) & Yüzde (\%) \\
\hline Cinsiyet & Kadın & 153 & 68,0 \\
Sinıf & Erkek & 72 & 32,0 \\
& Sinıfinı belirtmeyenler & 10 & 4,4 \\
& 1.sinıflar & 44 & 19,6 \\
2.sınıflar & 48 & 21,3 \\
Staj Yapma & 3.sinıflar & 53 & 23,6 \\
Durumu & 4.sinıflar & 70 & 31,1 \\
Evet & Hayıj & 122 & 54,2 \\
& 1 & 103 & 45,8 \\
& 2 & 58 & 47,5 \\
& Kütüphane & 64 & 52,5 \\
& Arşiv & 46 & 37,7 \\
& Büro & 20 & 16,4 \\
& Hem Kütüphane Hem de & 45 & 9,0 \\
& Arşiv veya Büro & & 36,9 \\
& & &
\end{tabular}

\section{Meslekî aidiyete ilişkin bulgular}

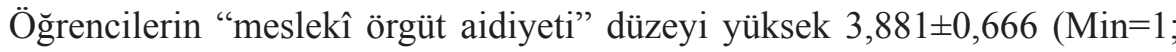
Maks=5) olarak saptanmıştır. (Tablo 3)

Tablo 3. Meslekî örgüt aidiyeti puan ortalamaları

\begin{tabular}{llllll}
\hline & N & Ort & Ss & Min. & Max. \\
\hline Meslekî Örgüt Aidiyeti & 225 & 3,881 & 0,666 & 1,000 & 5,000 \\
\hline
\end{tabular}

Öğrencilerin meslekî örgüt aidiyeti puanları, cinsiyet değişkenine göre, staj yeri değişkenine göre ve staj sayısı değişkenine göre anlamlı farklılık göstermemektedir ( $>0.05)$. Bununla birlikte, öğrencilerin meslekî örgüt aidiyeti puanları sınıf değişkenine göre anlamlı farklılık göstermektedir $(\mathrm{f}=3,729 ; \mathrm{p}=0.012<0.05)$. Farkın nedeni 2.sınıfların meslekî örgüt aidiyeti puanlarının 4.sınıfların meslekî örgüt aidiyeti puanlarından yüksek olmasıdır $(\mathrm{p}<0.05)$. Staj yapanların meslekî 
örgüt aidiyeti puanları $(\mathrm{x}=3,782)$, staj yapmayanların meslekî örgüt aidiyeti puanlarından $(\mathrm{x}=3,998)$ düşük bulunmuştur $(\mathrm{t}=-2,447$; $\mathrm{p}=0.015<0.05)$ (Tablo 4).

Tablo 4. Farklı değişkenlere göre meslekî örgüt aidiyeti düzeyleri

\begin{tabular}{|c|c|c|}
\hline Demografik Özellikler & $\mathbf{n}$ & Meslekî Örgüt Aidiyeti \\
\hline Cinsiyet & & Ort $\pm \mathrm{SS}$ \\
\hline Kadın & 153 & $3,936 \pm 0,627$ \\
\hline Erkek & 72 & $3,764 \pm 0,733$ \\
\hline $\mathbf{t}=$ & & 1,811 \\
\hline$p=$ & & 0,072 \\
\hline Sinıf & & Ort $\pm \mathrm{SS}$ \\
\hline 1 & 44 & $3,859 \pm 0,788$ \\
\hline 2 & 48 & $4,108 \pm 0,662$ \\
\hline 3 & 53 & $3,939 \pm 0,497$ \\
\hline 4 & 70 & $3,707 \pm 0,661$ \\
\hline $\mathbf{F}=$ & & 3,729 \\
\hline$p=$ & & 0,012 \\
\hline PostHoc $=$ & & $2>4(p<0.05)$ \\
\hline Staj Yapma Durumu & & Ort $\pm \mathrm{SS}$ \\
\hline Evet & 122 & $3,782 \pm 0,610$ \\
\hline Hayır & 103 & $3,998 \pm 0,712$ \\
\hline $\mathbf{t}=$ & & $-2,447$ \\
\hline$p=$ & & 0,015 \\
\hline Staj Sayısı & & Ort $\pm \mathrm{SS}$ \\
\hline 1 & 58 & $3,861 \pm 0,533$ \\
\hline 2 & 64 & $3,710 \pm 0,669$ \\
\hline $\mathbf{t}=$ & & 1,370 \\
\hline$p=$ & & 0,173 \\
\hline Staj Yeri & & Ort $\pm \mathrm{SS}$ \\
\hline Kütüphane & 46 & $3,792 \pm 0,675$ \\
\hline
\end{tabular}




\begin{tabular}{lll} 
Arşiv & 20 & $3,741 \pm 0,500$ \\
Büro & 11 & $3,517 \pm 0,677$ \\
$\begin{array}{l}\text { Hem kütüphane hem de } \\
\text { arşiv / büro }\end{array}$ & 45 & $3,854 \pm 0,568$ \\
$\mathbf{F}=$ & & 0,934 \\
$\mathbf{p}=$ & 0,427 \\
\hline
\end{tabular}

\section{Ölçek maddelerine göre meslekî aidiyet bulguları}

Araştırmaya katılan öğrencilerin meslekî örgüt aidiyeti ile ilgili ifadelere verdiği cevapların dağılımları Tablo 5 'te verilmektedir.

Tablo 5. Öğrencilerin meslekî örgüt aidiyeti ölçeğindeki ifadelere verdiği cevapların dağılımları

\begin{tabular}{|c|c|c|c|c|c|c|c|c|c|c|c|c|}
\hline & \multicolumn{2}{|c|}{ 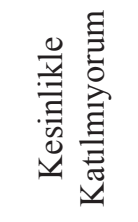 } & \multicolumn{2}{|c|}{ 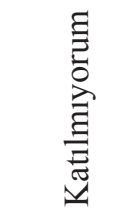 } & \multicolumn{2}{|c|}{ 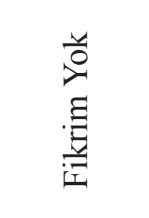 } & \multicolumn{2}{|c|}{ 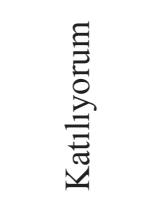 } & \multicolumn{2}{|c|}{ 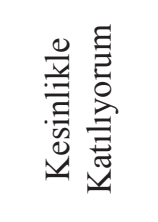 } & \multirow[b]{2}{*}{ Ort } & \multirow[b]{2}{*}{ Ss } \\
\hline & $\mathrm{f}$ & $\%$ & $\mathrm{f}$ & $\%$ & $\mathrm{f}$ & $\%$ & $\mathrm{f}$ & $\%$ & $\mathrm{f}$ & $\%$ & & \\
\hline $\begin{array}{l}\text { 1. Mesleğimin } \\
\text { toplumsal } \\
\text { imajına önem } \\
\text { verir, iyi } \\
\text { temsil etmeye } \\
\text { çalışırım. }\end{array}$ & 3 & 1,3 & 1 & 0,4 & 3 & 1,3 & 68 & 30,2 & 150 & 66,7 & 4,604 & 0,674 \\
\hline $\begin{array}{l}\text { 2. Mesleğimde } \\
\text { başarılı } \\
\text { olduğumu / } \\
\text { olacağımı } \\
\text { düşünüyorum. }\end{array}$ & 4 & 1,8 & 1 & 0,4 & 32 & 14,2 & 108 & 48,0 & 80 & 35,6 & 4,151 & 0,810 \\
\hline $\begin{array}{l}\text { 3. Bu mesleği } \\
\text { kendi isteğimle } \\
\text { tercih ettim. }\end{array}$ & 9 & 4,0 & 14 & 6,2 & 36 & 16,0 & 78 & 34,7 & 88 & 39,1 & 3,987 & 1,079 \\
\hline $\begin{array}{l}\text { 4. Mesleğimi } \\
\text { herkese } \\
\text { gururla } \\
\text { söylerim. }\end{array}$ & 5 & 2,2 & 11 & 4,9 & 48 & 21,3 & 81 & 36,0 & 80 & 35,6 & 3,978 & 0,984 \\
\hline
\end{tabular}


$\begin{array}{lllllllllllll}\text { 5. Bu mesleği } & 5 & 2,2 & 9 & 4,0 & 63 & 28,0 & 81 & 36,0 & 67 & 29,8 & 3,871 & 0,962\end{array}$ tercih etmiş

olmaktan

memnunum.

$\begin{array}{lllllllllllll}\text { 6. Mesleğimi } & 21 & 9,3 & 33 & 14,7 & 93 & 41,3 & 50 & 22,2 & 28 & 12,4 & 3,138 & 1,108\end{array}$ değiştirmeyi

asla

düşünmem.

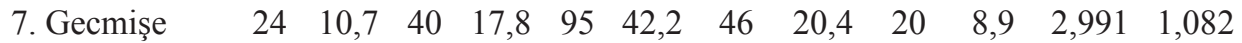
dönebilseydim

yine bu

mesleği

seçerdim.

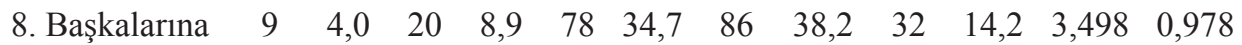
da bu

mesleği

tercih

etmelerini

öneririm.

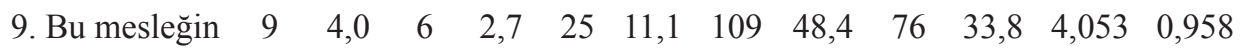
kişisel

gelişimime

katk1

sağladığını

düşünüyorum.

10. $\mathrm{Bu}$

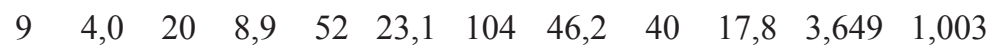

mesleğin

kişisel

ve ailevi

yaşantıma

katk1

sağladığını

düşünüyorum.

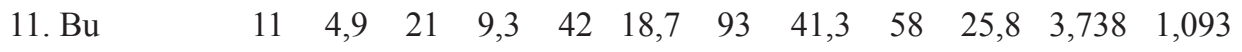
mesleğin

sosyalleşmeme

katk1

sağladığını

düşünüyorum. 


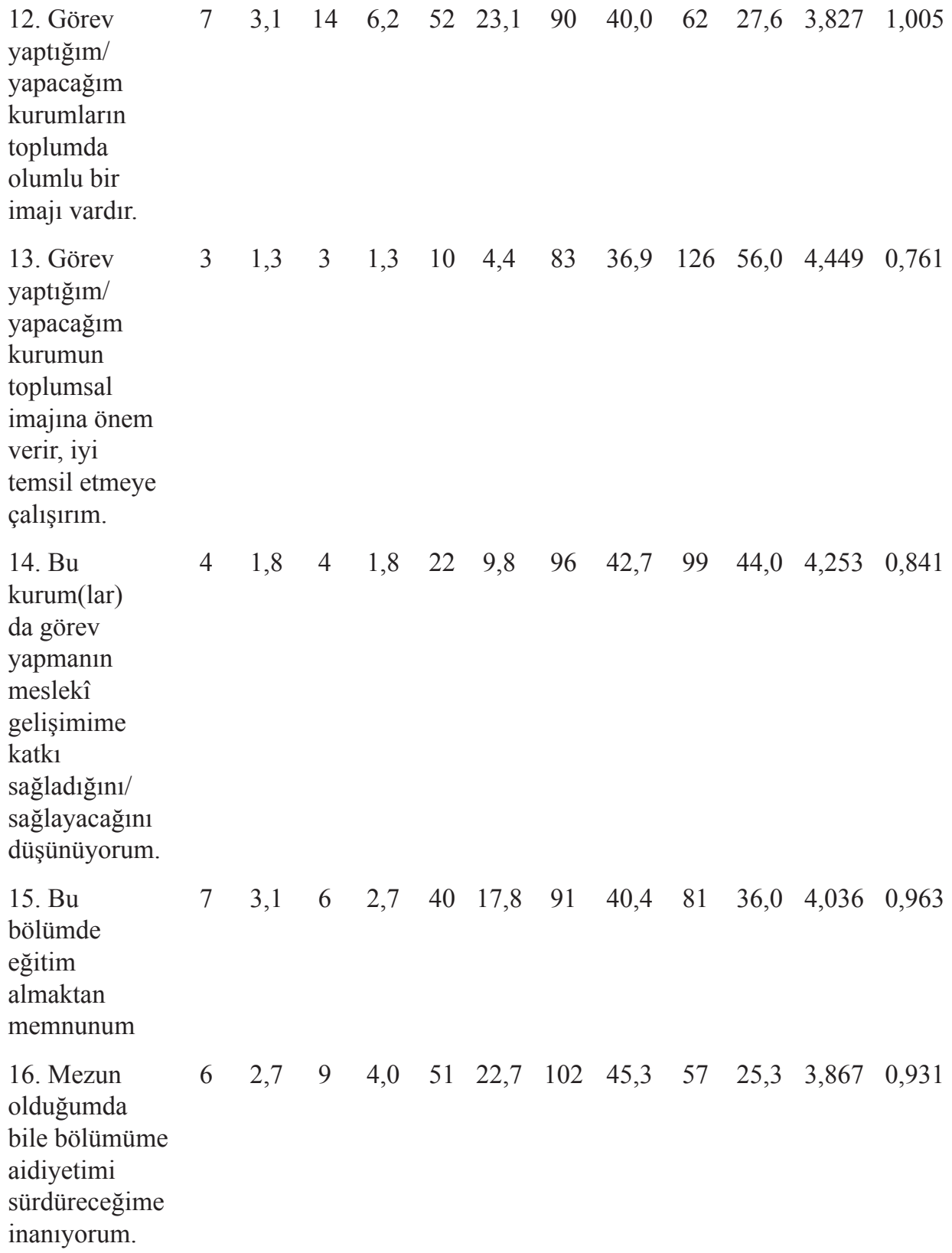

14. $\mathrm{Bu}$ kurum(lar) da görev yapmanın meslekî gelişimime katk1 sağladığını/ sağlayacağını düşünüyorum.

15. $\mathrm{Bu}$ bölümde $\begin{array}{llllllllllll}3 & 1,3 & 3 & 1,3 & 10 & 4,4 & 83 & 36,9 & 126 & 56,0 & 4,449 & 0,761\end{array}$ eğitim almaktan memnunum

16. Mezun olduğumda $\begin{array}{llllllllllll}4 & 1,8 & 4 & 1,8 & 22 & 9,8 & 96 & 42,7 & 99 & 44,0 & 4,253 & 0,841\end{array}$ bile bölümüme aidiyetimi sürdüreceğime inaniyorum.

Araştırmaya katılan öğrencilerin meslekî örgüt aidiyeti ile ilgili ifadelere verdiği cevaplar incelendiğinde; "Mesleğimin toplumsal imajına önem verir, iyi temsil etmeye çalışırım” "ifadesine öğrencilerin, \%1,3'ü (n=3) kesinlikle katılmı- 
yorum, \%0,4'ü $(n=1)$ katılmıyorum, \%1,3'ü $(n=3)$ fikrim yok, \%30,2'si $(n=68)$ katılıyorum, \%66,7'si (n=150) kesinlikle katılıyorum yanıtını vermiştir. Öğrencilerin "mesleğimin toplumsal imajına önem verir, iyi temsil etmeye çalışırım" ifadesine çok yüksek $(\overline{\mathrm{x}}=4,604)$ düzeyde katıldıkları saptanmıştır.

“Mesleğimde başarılı olacağımı düşünüyorum” ifadesine öğrencilerin, \%1,8'i $(n=4)$ kesinlikle katılmıyorum, \%0,4'ü $(n=1)$ katılmıyorum, \%14,2'si $(\mathrm{n}=32)$ fikrim yok, \%48,0'1 $(\mathrm{n}=108)$ kat1lyorum, \%35,6's1 $(\mathrm{n}=80)$ kesinlikle kat1lıyorum yanıtını vermiştir. Öğrencilerin "mesleğimde başarılı olacă̆ımı düşünüyorum" ifadesine yüksek $(\overline{\mathrm{x}}=4,151)$ düzeyde katıldıkları saptanmıştır.

“Bu mesleği kendi isteğimle tercih ettim” ifadesine öğrencilerin, \%4,0'1 $(\mathrm{n}=9)$ kesinlikle katılmıorum, \%6,2'si ( $\mathrm{n}=14)$ katılmıyorum, \%16,0'1 $(\mathrm{n}=36)$ fikrim yok, \%34,7'si (n=78) katıliyorum, \%39,1'i $(n=88)$ kesinlikle katıliyorum yanıtını vermiştir. Öğrencilerin "bu mesleği kendi isteğimle tercih ettim” ifadesine yüksek $(\overline{\mathrm{x}}=3,987)$ düzeyde katıld1kları saptanmıştır.

“Mesleğimi herkese gururla söylerim” ifadesine öğrencilerin, \%2,2'si (n=5) kesinlikle katılmiyorum, \%4,9'u (n=11) katılmiyorum, \%21,3'ü (n=48) fikrim yok, \%36,0'1 (n=81) katıliyorum, \%35,6's1 $(\mathrm{n}=80)$ kesinlikle kat1liyorum yanıtını vermiştir. Öğrencilerin "mesleğimi herkese gururla söylerim” ifadesine yüksek $(\overline{\mathrm{x}}=3,978)$ düzeyde katıldıkları saptanmıştır.

"Bu mesleği tercih etmiş olmaktan memnunum" ifadesine öğrencilerin, \%2,2'si (n=5) kesinlikle katılmiyorum, \%4,0'1 (n=9) katılmiyorum, \%28,0'1 $(\mathrm{n}=63)$ fikrim yok, \%36,0’1 (n=81) kat1liyorum, \%29,8'i (n=67) kesinlikle kat1l1yorum yanıtını vermiştir. Öğrencilerin "bu mesleği tercih etmiş olmaktan memnunum" ifadesine yüksek $(\overline{\mathrm{x}}=3,871)$ düzeyde katıldıkları saptanmıştır.

“Mesleğimi değişstirmeyi asla düşünmem” ifadesine öğrencilerin, \%9,3'ü $(n=21)$ kesinlikle katılmıorum, \%14,7'si (n=33) katılmıorum, \%41,3'ü (n=93) fikrim yok, \%22,2'si (n=50) katıliyorum, \%12,4'ü (n=28) kesinlikle kat1liyorum yanıtını vermiştir. Öğrencilerin “mesleğimi değiştirmeyi asla düşünmem” ifadesine orta $(\overline{\mathrm{x}}=3,138)$ düzeyde katıldıkları saptanmıştır.

“Geçmişe dönebilseydim yine bu mesleği seçerdim" ifadesine öğrencilerin, \%10,7'si $(\mathrm{n}=24)$ kesinlikle katılmiyorum, \%17,8'i $(\mathrm{n}=40)$ kat1lmiyorum, $\% 42,2$ 'si (n=95) fikrim yok, \%20,4'ü (n=46) kat1lıyorum, \%8,9'u (n=20) kesinlikle katılıyorum yanıtını vermiştir. Öğrencilerin "geçmişe dönebilseydim yine bu mesleği seçerdim " ifadesine orta $(\overline{\mathrm{x}}=2,991)$ düzeyde katıldıkları saptanmıştır.

“Başkalarına da bu mesleği tercih etmelerini öneririm” ifadesine öğrencilerin, \%4,0'1 (n=9) kesinlikle katılmıorum, \%8,9'u (n=20) katılmıyorum, \%34,7'si 
$(\mathrm{n}=78)$ fikrim yok, \%38,2'si (n=86) katıliyorum, \%14,2'si (n=32) kesinlikle katılıyorum yanıtını vermiştir. Öğrencilerin "başkalarına da bu mesleği tercih etmelerini öneririm " ifadesine yüksek $(\overline{\mathrm{x}}=3,498)$ düzeyde katıldıkları saptanmıştır.

“Bu mesleğin kişisel gelişsimime katkı sağladığını düşünüyorum” ifadesine öğrencilerin, \%4,0'1 (n=9) kesinlikle katılmıyorum, \%2,7'si (n=6) katılmıyorum, \%11,1'i (n=25) fikrim yok, \%48,4'ü (n=109) kat1liyorum, \%33,8'i (n=76) kesinlikle katılıyorum yanıtını vermiştir. Öğrencilerin "bu mesleğin kişisel gelişimime katkı sağladığını düşünüyorum” ifadesine yüksek $(\overline{\mathrm{x}}=4,053)$ düzeyde katıldıkları saptanmıştır.

"Bu mesleğin kişisel ve ailevi yaşantıma katkı sağladığını düşünüyorum” ifadesine öğrencilerin, \%4,0'1 (n=9) kesinlikle katılmıyorum, \%8,9'u (n=20) katılmiyorum, \%23,1'i (n=52) fikrim yok, \%46,2'si $(n=104)$ kat1lıorum, \%17,8'i $(\mathrm{n}=40)$ kesinlikle katılıyorum yanıtını vermiştir. Öğrencilerin "bu mesleğin kişisel ve ailevi yaşantıma katkı sağladı̆̆ını düşünüyorum” "ifadesine yüksek $(\overline{\mathrm{x}}=3,649)$ düzeyde katıldıkları saptanmıştır.

“Bu mesleğin sosyalleşmeme katkı sağladığını düşünüyorum” ifadesine öğrencilerin, \%4,9'u (n=11) kesinlikle katılmıyorum, \%9,3'ü (n=21) katılmıyorum, \%18,7'si (n=42) fikrim yok, \%41,3'ü (n=93) kat1liyorum, \%25,8'i (n=58) kesinlikle katılıyorum yanıtını vermiştir. Öğrencilerin "bu mesleğin sosyalleşmeme katkı sağladığını düşünüyorum” ifadesine yüksek $(\overline{\mathrm{x}}=3,738)$ düzeyde katıldıkları saptanmıştır.

“Görev yapacağım kurumların toplumda olumlu bir imajı vardır” ifadesine öğrencilerin, \%3,1'i (n=7) kesinlikle katılmıyorum, \%6,2'si (n=14) katılmıyorum, \%23,1'i (n=52) fikrim yok, \%40,0'1 $(\mathrm{n}=90)$ kat1liyorum, \%27,6's1 $(\mathrm{n}=62)$ kesinlikle katılıyorum yanıtını vermiştir. Öğrencilerin "görev yapacağım kurumların toplumda olumlu bir imajı vardır" ifadesine yüksek $(\overline{\mathrm{x}}=3,827)$ düzeyde katıldıkları saptanmıştır.

“Görev yapacağım kurumun toplumsal imajına önem verir, iyi temsil etmeye çalışırım" ifadesine öğrencilerin, \%1,3'ü $(\mathrm{n}=3)$ kesinlikle katılmıyorum, $\% 1,3$ 'ü $(\mathrm{n}=3)$ katılmiyorum, \%4,4'ü $(\mathrm{n}=10)$ fikrim yok, \%36,9'u (n=83) katıl1yorum, \%56,0’1 (n=126) kesinlikle katılıyorum yanıtını vermiştir. Öğrencilerin "görev yapacağım kurumun toplumsal imajına önem verir, iyi temsil etmeye çallşırım” ifadesine çok yüksek $(\overline{\mathrm{x}}=4,449)$ düzeyde katıldıkları saptanmıştır.

“Bu kurumlarda görev yapmanın meslekî gelişimime katkı sağlayacă̆ını düşünüyorum” ifadesine öğrencilerin, \%1,8'i $(\mathrm{n}=4)$ kesinlikle katılmıyorum, \%1,8'i (n=4) katılmıorum, \%9,8'i (n=22) fikrim yok, \%42,7'si (n=96) katılıyo- 
rum, \%44,0’1 (n=99) kesinlikle katılıyorum yanıtını vermiştir. Öğrencilerin “bu kurumlarda görev yapmanın meslekî gelişimime katkı sağlayacağını düşünüyorum " ifadesine çok yüksek ( $(\bar{x}=4,253)$ düzeyde katıldıkları saptanmıştır.

“Ви bölümde eğitim almaktan memnunum” ifadesine öğrencilerin, \%3,1'i $(\mathrm{n}=7)$ kesinlikle katılmıyorum, \%2,7'si $(\mathrm{n}=6)$ katılmıorum, \%17,8'i $(\mathrm{n}=40)$ fikrim yok, \%40,4'ü (n=91) kat1lyorum, \%36,0'1 $(\mathrm{n}=81)$ kesinlikle katıliyorum yanıtını vermiştir. Öğrencilerin “bu bölümde eğitim almaktan memnunum” ifadesine yüksek $(\bar{x}=4,036)$ düzeyde katıldıkları saptanmıştır.

“Mezun olduğumda bile bölümüme aidiyetimi sürdüreceğime inanıyorum” ifadesine öğrencilerin, \%2,7'si (n=6) kesinlikle katılmıyorum, \%4,0'1 (n=9) katılmiyorum, \%22,7'si (n=51) fikrim yok, \%45,3'ü (n=102) katıliyorum, \%25,3'ü $(\mathrm{n}=57)$ kesinlikle katılıyorum yanıtını vermiştir. Öğrencilerin "mezun olduğumda bile bölümüme aidiyetimi sürdüreceğime inanıyorum” ifadesine yüksek $(\overline{\mathrm{x}}=3,867)$ düzeyde katıldıkları saptanmıştır.

\section{Sonuç}

Bilgi ve Belge Yönetimi alanında yapılan stajlara ilişkin çeşitli araştırmalar bulunmaktadır. Efe, Zan ve Binici (2014); Furat ve Keskin (2015); Sağlik (2016); Yalçınkaya ve Saydam (2017) çalışmalarında farklı bulgular elde etmiştir. Bu çalışmalarda öğrencilerin staj uygulamasından faydalı deneyimler kazandıkları, gerçek çalışma ortamını görme ve işleriyle ilgili araç ve gereçleri kullanma firsatı buldukları, iş hayatına bakışlarının olumlu yönde değiştiği ifade edilmiştir.

Furat ve Keskin'in İstanbul Üniversitesi BBY bölümü öğrencileri ile yaptıkları çalışmada, "öğrencilerin staj yerlerinde çoğunlukla motive edildikleri, eğitimden kaynaklı bilimsel birikimlerini başarılı bir biçimde değerlendirebildikleri, meslekî faaliyet sahalarının tamamında sorumluluk aldıkları, sorumluluk üstlenmelerinin teşvik edildiği, öğrencilerin kendilerine yüklenen sorumlulukları başarılı bir şekilde gerçekleştirdikleri, meslek çalışanları ve hizmet alıcılarıyla olumlu ilişkiler kurdukları, kurum tarafından kurum personeli gibi algılandıkları ve staj sonrasında stajlarını gerçekleştirdikleri kurumdan genellikle çalışma teklifi aldıkları anlaşılmıştır."

Yalçınkaya ve Saydam'ın Marmara Üniversitesi BBY bölümü öğrencileri ile yaptıkları çalışmada staj süreçlerinin öğrencilerin meslekî beklentilerine etkisi incelenmiş ve öğrencilerin büyük bir kısmının meslekî gelecek konusunda staj

4 M. F. Furat - İ. Keskin, "İstanbul Üniversitesi Bilgi ve Belge Yönetimi bölümü öğrencilerinde arşiv stajı algısı-Uygulamalı bir çalışma”, Bilgi ve Belge Araştırmaları, (3), 2016, s. 20. 
yapmaktan olumlu yönde etkilendiği saptanmıştır. İki zorunlu staj uygulaması bulunan MÜBBYB'de ilk stajlarını yapan öğrencilerle ikinci stajlarını yapanlar arasında mesleğe bakış açısından farklılık olup olmadığını ölçmek için bağımsız t testi uygulanmıştır. İlk stajını yapanlarla, ikinci stajını yapanların meslekî anlamda beklentileri arasındaki farkın ikinci stajını yapanlar yönünde olumlu olması meslekî anlamda olgunlaşmayla açıklanabilecek bir etken olarak yorumlanmıştır. ${ }^{5}$

Sağlık'ın belirli bir iş tecrübesine sahip BBY mezunlarına sorduğu sorular ile stajların niteliğini sorgulayan çalışmasında, stajların meslekte ne yapılacağına dair fikir verebilecek bir süreye sahip olduğu, yetenekleri geliştirip, iş tecrübesi kazandırdığı saptanmış, bununla birlikte stajların süre bakımından öğrencileri mesleğe hazırlamak konusunda yetersiz kalabileceği, öğrencilerin staj süreleri ne kadar uzun ve verimli olursa öğrencilerin kendilerini mesleğe o derecede hazır hissedecek oldukları belirtilmiştir. Stajların uzmanlaşma alanı konusunda bir fikir verip vermediği ya da vermediği konusunda ise bölüm mezunlarının aklında soru işareti bulunduğu ifade edilmektedir. ${ }^{6}$

Bilgi ve Belge Yönetimi bölümü öğrencilerinin öğrenim gördükleri alana dair meslekî aidiyet düzeylerini Marmara Üniversitesi örneğinde inceleme amac1 taşıyan bu çalışmada ise şu sonuçlar elde edilmiştir: MÜBBYB öğrencilerinin öğrenim gördükleri alana dair meslekî örgüt aidiyet düzeyleri yüksektir. Ölçek maddelerine katılım düzeyleri Tablo 6'da listelenen öğrencilerin çok yüksek düzeyde katıldıkları maddeler, toplumsal imaj, temsiliyet ve meslekî gelişim ile ilgilidir. Öğrenciler, hem mesleğin hem de görev yapacakları kurumun toplumsal imajına önem vermekte ve iyi temsil etmeye çalışacaklarını ifade etmektedir. Öğrencilere göre, görev yaptıkları kurumların toplum içinde olumlu bir imajı bulunmaktadır. Dahası, öğrenciler, staj yaptıkları kurumlarda görev yapmanın meslekî gelişimlerine katkı sağlayacağına çok yüksek düzeyde inanmaktadır. (Bkz. Tablo 6) Bütün bu bulgular, daha önce yapılan çalışmaların bulguları ile örtüşmektedir.

Öğrenciler, bölümlerinde eğitim almaktan memnundur ve mezun olduklarında dahi bölümlerine aidiyetlerini sürdürecekleri fikrine yüksek

5 B. Yalçınkaya - V. Saydam, "Staj süreçlerinin öğrencilerin mesleki beklentilerine etkisi: Marmara Üniversitesi Bilgi ve Belge Yönetimi Bölümü Üzerine Bir İnceleme”, Arşiv Dünyast, (20), 2017, s. 1-20.

6 Ö. Sağlık, "Bilgi ve belge yönetimi eğitiminde uygulamanın önemi: Stajlar üzerine bir araştırma”, I. Uluslararası Bilgi ve Belge Yönetimi Bölümü Öğrenci Kongresi 25-26 Nisan 2014, ed. Güssün Güneş, İstanbul, 2016, s. 9-18. 
düzeyde katılmaktadır. Öğrenciler, eğitimini aldıkları mesleğin kişisel gelişimlerine, kişisel ve ailevi yaşantılarına ve sosyalleşmelerine katkı sağladığını düşünmektedir. Öğrenciler, meslekte başarılı olduklarını ve olacaklarını düşünmekte, bu mesleği kendi istekleri ile tercih ettiklerini, başkalarına da bu mesleği önerebileceklerini ve mesleklerini herkese gururla söyleyeceklerini yüksek düzeyde ifade etmektedir. Bununla birlikte, "Mesleğimi değiştirmeyi asla düşünmem" ve "Geçmişe dönebilseydim yine bu mesleği seçerdim" maddelerine orta düzeyde katıldıkları saptanmıştır. (Bkz. Tablo 6) $\mathrm{Bu}$ da öğrencilerin bölümlerini veya mesleklerini değiştirme imkânı bulduklarında kararsız kalabilecekleri ihtimalini doğurmaktadır.

Öğrencilerin meslekî örgüt aidiyeti puanları, cinsiyet değişkenine göre, staj yeri değişkenine göre ve staj sayısı değişkenine göre anlamlı farklılık göstermezken, sınıf değişkenine ve staj yapıp yapmama durumuna göre anlamlı farklılık göstermektedir. Anlamlı fark göstermeyen değişkenlerin öğrencilerin meslekî aidiyet düzeylerine etkisi bulunmazken, anlamlı fark gösteren sınıf ve staj yapıp yapmama durumu meslekî aidiyet düzeylerini etkilemektedir.

İstatistikî sonuçlara göre, 2.sınıfların meslekî örgüt aidiyeti puanları, 4.sınıfların meslekî örgüt aidiyeti puanlarından yüksektir. Buna paralel olarak staj yapmayanların meslekî örgüt aidiyeti staj yapanların meslekî örgüt aidiyeti puanlarından yüksektir. Yani, iki staj yapmış olan son sınıfların mezun olma aşamasına yaklaştıkları bölümde eğitimini aldıkları alana dair aidiyet düzeyleri henüz hiç staj yapmayan ikinci sınıfların aidiyet düzeylerinden düşüktür. Yalçınkaya ve Saydam'ın bulguları ile uyum sağlamayan bu öngörülemez veri, 2003 yılında Türk Kütüphaneciliği Dergisi'nde yayınlanan bir görüş yazısının savını desteklemektedir. Hacettepe Üniversitesi Bilgi ve Belge Yönetimi Bölümü son sınıf öğrencisi Dilek Varol'un "Staj uygulamaları üzerine kişisel gözlemler" başlıklı yazısı, öğrencilerin stajlarda yaşadığı olumsuz durumları anlatmakta, bunun da meslekî aidiyet ve bağlılık için zararlı olduğunu ifade etmektedir. $^{7}$

Stajlar, Bilgi ve Belge Yönetimi öğreniminin meslekî aidiyeti etkileyen dikkate değer bir unsurudur. Bu çalışmada elde edilen veriler, öğrencilerin stajları planlanırken doğru kurumların seçilmesi konusunun ne denli önemli olduğunu göstermiştir.

7 D. Varol, "Staj uygulamaları üzerine kişisel gözlemler”, Türk Kütüphaneciliği, 17(2), 2003, s. 199. 
Tablo 6. Öğrencilerin meslekî örgüt aidiyeti ölçeğindeki ifadelere katılım durumu dağ 1 lımları

\section{Madde}

Düzey

1. Mesleğimin toplumsal imajına önem verir, iyi temsil etmeye

Çok yüksek çalışırım.

2. Mesleğimde başarılı olduğumu /olacağımı düşünüyorum.

Yüksek

3. Bu mesleği kendi isteğimle tercih ettim.

Yüksek

4. Mesleğimi herkese gururla söylerim.

Yüksek

5. Bu mesleği tercih etmiş olmaktan memnunum.

Yüksek

6. Mesleğimi değiştirmeyi asla düşünmem.

Orta

7. Gecmişe dönebilseydim yine bu mesleği seçerdim.

Orta

8. Başkalarına da bu mesleği tercih etmelerini öneririm.

Yüksek

9. Bu mesleğin kişisel gelişimime katkı sağladığını düşünüyorum.

Yüksek

10. Bu mesleğin kişisel ve ailevi yaşantıma katkı sağladığını

Yüksek düşünüyorum.

11. Bu mesleğin sosyalleşmeme katkı sağladığını düşünüyorum.

Yüksek

12. Görev yaptığım/yapacağım kurumların toplumda olumlu bir imajı

Yüksek vardır.

13. Görev yaptı̆̆ım/ yapacağım kurumun toplumsal imajına önem Çok yüksek verir, iyi temsil etmeye çalışırım.

14. Bu kurum(lar)da görev yapmanın meslekî gelişimime katkı

Çok yüksek sağladığını/sağlayacağını düşünüyorum.

15. Bu bölümde eğitim almaktan memnunum.

Yüksek

16. Mezun olduğumda bile bölümüme aidiyetimi sürdüreceğime inaniyorum.

Yüksek 


\section{Kaynakça}

Efe, A. - Zan, B. U. - Binici, K., "Bilgi ve belge yönetimi öğrencilerinin staj uygulamaları üzerine bir araştırma", Ankara Üniversitesi Bilgi ve Belge Yönetimi Bölümü 60. Yıl Armă̆an Kitabı, ed. N. Özel - N. Er-Koçoğlu, Ankara, Ankara Üniversitesi Bilgi ve Belge Yönetimi Bölümü, 2014.

Furat, M. F. - Keskin, İ., "İstanbul Üniversitesi Bilgi ve Belge Yönetimi bölümü öğrencilerinde arşiv stajı algısı: Uygulamalı bir çalışma”, Bilgi ve Belge Araştırmaları, (3), 2015.

Greenfield, A. C. - Norman, C. S. - Wier, B., "The effect of ethical orientation and professional commitment on earnings management behavior", Journal of Business Ethics, 83, 2008..

Kardeş Selimoğlu, S. - Yeşilçelebi, G., "Meslekî aidiyetin bağımsız denetim kalitesi üzerine etkisi: Bağımsız denetçiler üzerine bir araştırma", Muhasebe ve Finansman Dergisi, (64), 2014, (DOI: 10.25095/mufad.396489)

Keskin, R. - Pakdemirli, M.N., "Meslekî aidiyet ölçeği: Bir ölçek geliştirme, geçerlilik ve güvenirlik çalışması", Journal of International Social Research, 9, 2016.

Lee, K. - Carswell, J. J. - Allen, N. J., A meta-analytic review of occupational commitment: Relations with person- and work-related variables, Journal of Applied Psychology, 85 (5), 2000.

Lord, A. T. - DeZoort, F. T., "The impact of commitment and moral reasoning on auditors' responses to social influence pressure", Accounting, Organizations and Society, 26, 2001.

Sağlık, Ö., "Bilgi ve belge yönetimi eğitiminde uygulamanın önemi: Stajlar üzerine bir araştırma”, I. Uluslararası Bilgi ve Belge Yönetimi Bölümü Öğrenci Kongresi 25-26 Nisan 2014, ed. Güssün Güneş, İstanbul, 2016.

Varol, D., "Staj uygulamaları üzerine kişisel gözlemler", Türk Kütüphaneciliği, 17, 2, 2003.

Yalçınkaya, B. - Saydam, V., "Staj süreçlerinin öğrencilerin meslekî beklentilerine etkisi: Marmara Üniversitesi Bilgi ve Belge Yönetimi bölümü üzerine bir inceleme", Arşiv Dünyası, (20), 2017. 
